TaI, T. Y. \& van Heyningen, W. E. (1951). J. gen. Microbiol. 5, 110-120.

\title{
Bacteriolysis by a Species of Streptomyces
}

\author{
By T. Y. TAI* and W. E. VAN HEYNINGEN \\ Sir William Dunn School of Pathology, University of Oxford
}

\begin{abstract}
SUMMARY: The lysis of dead Bacterium coli by concentrates prepared from filtrates of a Streptomyces sp. is probably due to proteolysis. In any event the lysis can be accounted for by proteolysis, even if the action of other bacteriolytic enzymes cannot be excluded. The streptomyces preparation contains at least two proteolytic enzymes, one digesting casein and the other digesting protein(s) present in Bact. coli. The substrates of the autolytic enzymes of Bact. coli are probably different from those of the streptomyces enzymes.
\end{abstract}

The bacteriolytic activity of actinomycetes has been discussed by several authors (e.g. Waksman, 1947; Welsch, 1947; Jones, Swallow \& Webb, 1948). Dead Gram-negative, dead Gram-positive, living Gram-positive, and living Gram-negative organisms, in that order of susceptibility, are said to be lysed by sterile culture-filtrates of certain species of actinomycetes. The lysis of living organisms is open to doubt because it is difficult, if not impossible, to determine whether the organisms that are lysed in a suspension containing living organisms are living or not. The lysis of organisms by cultures of actinomycetes is thought to consist of two stages: the killing of the organisms by an antibiotic, and the lysis of the dead organisms by a lytic agent.

It seemed to us that this lytic agent might be one or more proteolytic enzymes. Welsch (1947) contended that the bacteriolytic activity of Streptomyces albus $\mathrm{G}$ was not due to proteolysis only. He stated that 'des actinomycétines concentrées, mais encore très impures, ont le même activité bactériolytique par mgr. d'N protéique que des solutions de trypsine cristallisée, sans posséder cependant leur activité protéolytique'. The proteolytic activities of the streptomyces preparation and the crystalline trypsin were compared in their action on gelatin, casein and coagulated serum. This does not exclude the possibility that the streptomyces preparation might have contained proteolytic enzymes, relatively inactive towards these particular proteins, but active against other proteins that might be present in the lysable micro-organisms.

Jones et al. (1948) showed that culture filtrates of various species of actinomycetes used by them contained at least two proteolytic enzymes. They stated that the bacteriolysis by actinomycetes was due to these enzymes, but did not show that proteolysis took place during bacteriolysis.

We have shown that the bacteriolytic activity of a Streptomyces sp. isolated from the soil can be accounted for by its proteolytic activity, and that its proteolytic activity is due to at least two enzymes, one of which is caseinolytic and the other capable of digesting the protein(s) present in certain bacteria.

\footnotetext{
* Present address: National Medical College of Shanghai.
} 


\section{METHODS}

Isolation of culture. Soil samples were selected at random from fields in Oxford. They were mixed with distilled water and allowed to settle at room temperature. Water-agar plates incorporating living Staphylococcus aureus and dead Bact. coli were inoculated with the supernatant fluid and incubated for 3 days at $37^{\circ}$. Colonies of presumptive actinomycetes that had clear zones of lysed Staph. aureus or Bact. coli around them were isolated and transferred for sporulation to mineral agar slopes containing $2 \%$ sucrose. Altogether ten strains were isolated; four were highly active against living and dead Staph. aureus and Bact. coli; two were moderately active; four were inactive. The most active strain was chosen for further study and was identified by Dr Kathleen Crawford as a species of Streptomyces.

Production of lytic filtrates. After several trials a tryptic digest of casein was found to be suitable for the production of bacteriolytically-active culture filtrates on a large scale. Casein (300 g.; British Drug Houses Ltd., light white) is mixed with $300 \mathrm{ml}$. ethanol and uniformly suspended by stirring in 31 . of warm tap-water. The $\mathrm{pH}$ is adjusted to $8 \cdot 5,8 \mathrm{~g}$. commercial crude trypsin (Harrington) are added, and the mixture is maintained at $50-55^{\circ}$ for $12-18 \mathrm{hr}$. During the first few hours the $\mathrm{pH}$ is maintained at 8.5 by frequent additions of $10 \mathrm{~N}-\mathrm{NaOH}$. After $6-9 \mathrm{hr}$. a further $8 \mathrm{~g}$. of crude trypsin are added. Chloroform $(1 \%)$ is added to prevent the growth of bacteria. The digestion is complete, after $12-18 \mathrm{hr}$., when a sample no longer precipitates with an equal volume of $10 \%(\mathrm{w} / \mathrm{v})$ trichloroacetic acid. The digest is then boiled for $1 \mathrm{hr}$., filtered, and made up to $3 \mathrm{l}$. The final medium had the following composition: $\mathrm{NaNO}_{3}, 2 \cdot 0$ g.; $\mathrm{K}_{2} \mathrm{HPO}_{4}, 1 \cdot 0$ g.; $\mathrm{KCl}, 1.0 \mathrm{~g}$.; $\mathrm{MgSO}_{4} .7 \mathrm{H}_{2} \mathrm{O}, 1.0$ g.; tryptic

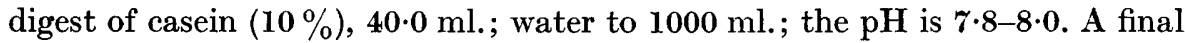
concentration of $0.4 \%(\mathrm{v} / \mathrm{v})$ of trypsin-digested casein is the optimum for the production of bacteriolytically active filtrates. With higher or lower concentrations of casein digest less active filtrates are obtained.

The medium was distributed in 4 or 8 l. quantities in 5 or $10 \mathrm{l}$. Pyrex bottles, inoculated with a 4-day growth of the Streptomyces sp. on the same medium, and incubated at $24^{\circ}$ or $37^{\circ}$. During incubation the cultures were aerated with one volume of air per volume of culture fluid per minute. About the same concentration of lytic substances is reached whether the cultures are incubated for 5-6 days at $24^{\circ}$, or for $48 \mathrm{hr}$. at $37^{\circ}$.

Concentration of lytic agent. The cultures were clarified in a Sharples centrifuge and the clear supernatants concentrated about 30-fold by evaporating-off the water (12-14 l./hr.) under reduced pressure at $36^{\circ}$ (van Heyningen, 1949). The lytic substances were precipitated from the concentrate by the addition of $\left(\mathrm{NH}_{4}\right)_{2} \mathrm{SO}_{4}$ to 0.65 saturation. The precipitate was suspended in a small volume of water, dialysed against running tap-water for 2 days, and freeze-dried, the dried product being kept in a desiccator. Stock concentrated solutions of the crude product in $66 \%$ glycerol were kept in a refrigerator. These solutions retain their activity without loss for several months.

Estimation of proteolytic activity. Two substrates were used: (i) a $1 \%(w / v)$ 
solution of casein (British Drug Houses Ltd., light white) in $0.67 \mathrm{M}$ phosphate buffer ( $\mathrm{pH} \mathrm{8.0)}$; (ii) a $1 \%$ (dry wt./v) suspension of Bact. coli in the same buffer. The casein solution was made by suspending $1 \mathrm{~g}$. casein in $100 \mathrm{ml}$. buffer and heating in a boiling water-bath for $10 \mathrm{~min}$. The resulting solution was turbid. The bacterial suspension was made as follows : over-night cultures of Bact. coli on nutrient agar in Roux bottles were harvested, washed three times with distilled water and resuspended in distilled water. The dry weight of $1 \mathrm{ml}$. samples of the suspension was determined, and the organisms spun down and resuspended in buffer to make a $1 \%$ (dry wt./v) suspension. This suspension was then autoclaved at $120^{\circ}$ for $20 \mathrm{~min}$.

The method used for estimating proteolytic activity was a modification of Kunitz's (1947) method. Equal volumes (10 ml.) of enzyme solution in phosphate buffer ( $\mathrm{pH} \mathrm{8.0)}$ and substrate solution or suspension, both previously warmed to $37^{\circ}$, are mixed together. Duplieate $4 \mathrm{ml}$. samples are immediately withdrawn ( $0 \mathrm{~min}$.) and each is discharged into $4 \mathrm{ml}$. of $6 \%(\mathrm{w} / \mathrm{v})$ trichloroacetic acid solution. The rest of the mixture is incubated at $37^{\circ}$ for $20 \mathrm{~min}$., when two more $4 \mathrm{ml}$. samples are withdrawn and discharged into trichloroacetic acid. The trichloroacetic acid-precipitated samples are then filtered through Whatman No. 1 paper and the optical density of the filtrates at $280 \mathrm{~m} \mu .\left(\mathrm{D}_{280}\right)$ is determined in a Beckman DU photoelectric absorption spectrophotometer. The value for the increase in $\mathrm{D}_{280}$ is then translated into units of proteolytic activity by means of a standard curve. A unit of proteolytic activity (Cas. units where casein is the substrate; Col. units where Bact. coli is the substrate) is defined as that amount of enzyme which, under the conditions described, will hydrolyse the substrate at such a rate that in $\mathbf{2 0} \mathrm{min}$. there is an increase of 0.30 in the $\mathrm{D}_{280}$ of the trichloroacetic acid filtrate. The standard curve is derived from the activity curve, which is constructed as follows: increasing concentrations of enzyme are incubated with the substrate for $20 \mathrm{~min}$. and the values for increase in $\mathrm{D}_{280}$ of the resulting trichloroacetic filtrates are determined in the usual way. These are then plotted against the relative enzyme concentrations, as is shown in Fig. 1 for the activity curves for the crude streptomyces preparation (A), crude commercial trypsin (B), and crystalline trypsin (C), acting on Bact. coli suspension. Fig. 2 shows the standard curves derived from these curves. A tangent is drawn to the initial portion of each activity curve; from this tangent the amount of proteolytic agent causing an increase of 0.30 in the $D_{280}$ of the trichloroacetic acid filtrate is read. This is the unit. The data on a smooth line passing through the points of the activity curve are then replotted on the standard curve so that multiples of units fall on convenient increments of the abscissa.

Objection might be raised on the grounds that the liberation from autoclaved Bact. coli of trichloroacetic acid-soluble substances absorbing at $280 \mathrm{~m} \mu$. might not be a measure of the action of a proteolytic enzyme, but of an enzyme liberating substances like purines and pyrimidines that absorb ultra-violet light. However, such an objection does not apply to this work. The absorption spectra of the trichloroacetic acid-soluble material resulting from the action of (a) crystalline trypsin on autoclaved Bact. coli, $(b)$ the streptomyces preparation 
on autoclaved Bact. coli, $(c)$ crystalline trypsin on casein, and $(d)$ the streptomyces preparation on casein were all very similar, as can be seen from Fig. 3. These spectra were determined by Dr G. V. R. Born. None of the preparations had absorption maxima in the ranges not shown in the figure. The crude streptomyces preparation liberated trichloroacetic acid-soluble substances from autoclaved Bact. coli with much the same absorption spectrum as those

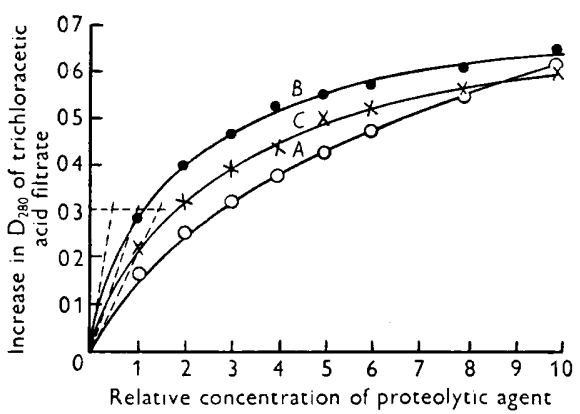

Fig. 1

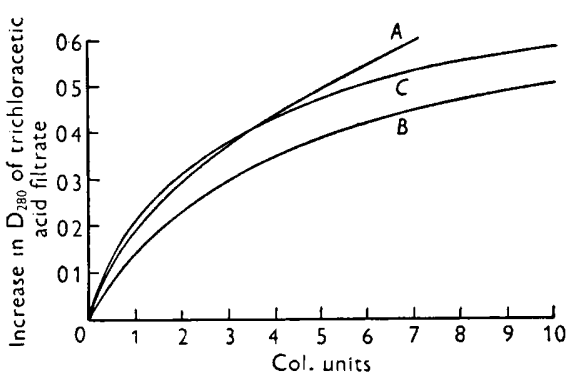

Fig. 2

Fig. 1. Proteolytic activity curves for the streptomyces preparation $(A)$, crude trypsin $(B)$, and crystalline trypsin $(C)$, with autoclaved Bact. coli as substrate.

Fig. 2. Standard curves derived from curves in Fig. 1.

liberated by crystalline trypsin from casein. These curves show that it would probably be better to measure absorption at $275 \mathrm{~m} \mu$. rather than at $280 \mathrm{~m} \mu$., as is usual in the estimation of proteolytic activity.

Estimation of bacteriolytic activity. Bacteriolytic activity is estimated by measuring the percentage lysis of a standard suspension of autoclaved Bact. coli by the lytic preparation in $\mathbf{1 5}$ min. under defined conditions. Percentage lysis is translated into bacteriolytic units (Lyt. units) by means of a standard curve. The bacteriolytic unit is defined as that amount of lysin which under the conditions described will produce $30 \%$ lysis of a standard suspension of Bact. coli in $15 \mathrm{~min}$.

The standard suspension of Bact. coli is made from twice-washed organisms, resuspended in phosphate buffer $\mathrm{pH} 8.0$, and autoclaved at $120^{\circ}$ for $20 \mathrm{~min}$. After standing overnight at $4^{\circ}$ the concentration of the suspension is adjusted so as to have the same optical density as double-strength Thompson's (1946) inorganic grey solution, as compared in a visual colorimeter with a tricolour green filter in the eyepiece. This is equivalent to a $0.04 \%$ (dry wt./v) suspension of the organism. Freshly autoclaved Bact. coli is more readily lysed by the streptomyces preparation and by crude and crystalline trypsin than suspensions that have been kept at $4^{\circ}$ for some time. After $1 \mathrm{hr}$. at $4^{\circ}$ the lysability of the suspension becomes constant and remains so for at least 3 weeks. Therefore autoclaved suspensions of Bact. coli are always kept overnight at $4^{\circ}$ before being used.

When dense bacterial suspensions, such as those used here, are compared with inorganic grey solution in a visual colorimeter in such a way that the light 
path $(S)$ through the standard is kept constant while the length of the light path $(U)$ through the suspension is varied then the ratio $S / U$ will be a linear function of the density of the suspension. If $U$ is kept constant and $S$ is varied then the relationship between $S / U$ and the density of the suspension is not linear (van Heyningen, unpublished work). Our readings of bacterial density were made in a visual colorimeter with double-strength inorganic grey solution

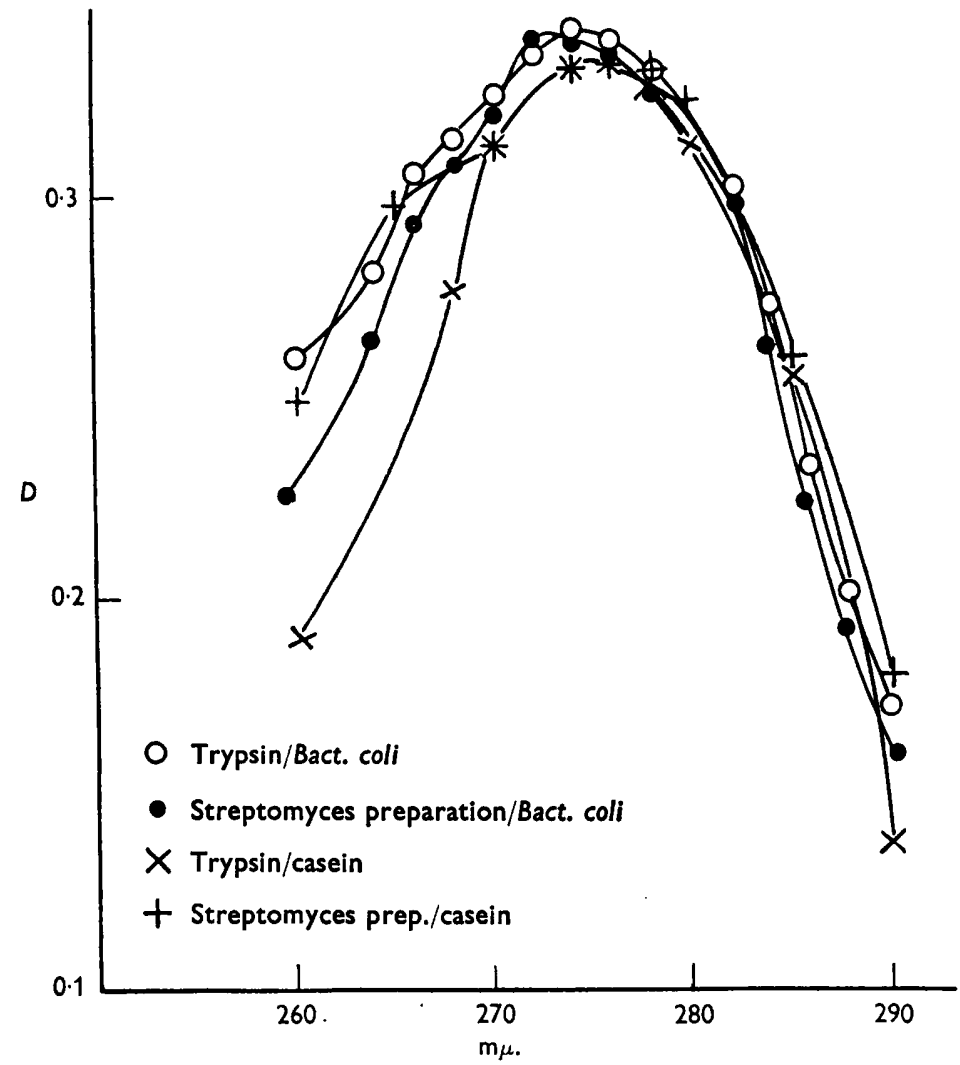

Fig. 3. Ultra-violet absorption spectra of trichloroacetic acid-soluble material liberated by crystalline trypsin from autoclaved Bact. coli and casein, and by the streptomyces preparation from the same substrates.

as standard at a constant depth. The ratio $S / U$ is a direct measure of the relative concentration of bacteria. More elaborate apparatus, such as is used by Welsch (1947), is unnecessary.

To measure bacteriolytic activity $1 \mathrm{ml}$. of a solution of the lytic agent in $0.67 \mathrm{M}$ phosphate buffer $\mathrm{pH} 8.0$ is mixed with $4 \mathrm{ml}$. of the autoclaved Bact. coli suspension previously warmed. The turbidities of the mixture at 0 and $15 \mathrm{~min}$. are compared and the percentage lysis is calculated from the expression $100-100 \frac{\mathrm{U}_{0 \mathrm{~min} .}}{\mathrm{U}_{15 \mathrm{~min}} \text {. }}$. Activity and standard curves are prepared in the same way as those for the estimation of proteolytic activity. These are shown in Figs. 4 and 5. Samples causing more than $50 \%$ lysis are diluted. 
Other determinations. Viable counts of bacteria were made by the method of Tai \& van Heyningen (1950). Nitrogen was determined by the micro-Kjeldahl method. Values of $\mathrm{pH}$ were determined electrometrically using a glass electrode.

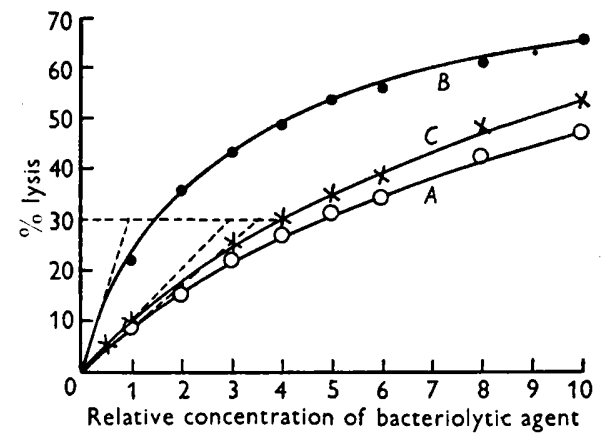

Fig. 4

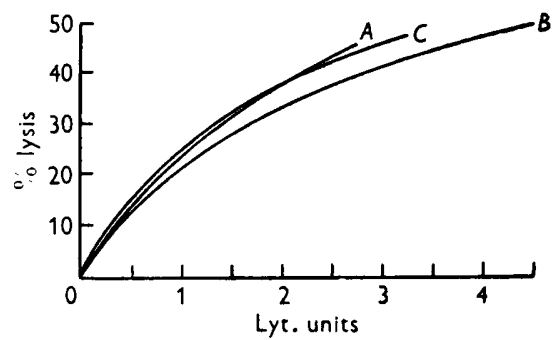

Fig. 5

Fig. 4. Bacteriolytic activity curves for the streptomyces preparation $(A)$, crude trypsin $(B)$, and crystalline trypsin $(C)$, acting on autoclaved Bact. coli cells.

Fig. 5. Standard curves derived from curves in Fig. 4.

\section{RESULTS}

Adsorption of bacteriolytic and proteolytic enzymes

by autoclaved Bact. coli

Autoclaved Bact. coli cells adsorb the bacteriolytic and proteolytic enzymes of the Streptomyces strain used from solution; living cells of Bact. coli do not adsorb these enzymes.

A $0.32 \%$ (dry wt./v) suspension of Bact. coli was made in solutions of the streptomyces preparation in phosphate buffer $\mathrm{pH}$ 8. The suspensions were stood in ice for $\mathbf{3 0} \mathrm{min}$., the organisms were spun down, and the bacteriolytic activity (Lyt. units) and caseinolytic activity (Cas. units) of the supernatant fluids determined and compared with the values of the preparation before treatment with Bact. coli. About 60-70\% of the Lyt. units were adsorbed and $\mathbf{2 0 - 3 0} \%$ of the Cas. units. It was thus obvious that the bacteriolytic enzyme(s) was not identical with the caseinolytic enzyme(s).

The presence of salts (e.g. $\mathbf{0} \cdot \mathbf{6 7} \mathrm{m}$ phosphate buffer) inhibited the adsorption of Lyt. and Cas. units, particularly the latter. When the adsorption of enzymic activity was done in the presence of distilled water, rather than in the buffer usually used for adsorption experiments, the adsorption of Lyt. units amounted to about $85 \%$ and that of Cas. units to about $75 \%$. Welsch (1947) found that salts inhibited the lysis of bacteria by his streptomyces preparation; this is possibly due to inhibition of adsorption of bacteriolytic enzymes.

When similar experiments were done with crude trypsin it was found that 60-70\% of the Lyt. units were adsorbed and $40-45 \%$ of the Cas. units. The bacteriolytic activity of crude trypsin is also not solely due to its caseinolytic activity. When pure, crystalline trypsin was used the adsorption of bacteriolytic and caseinolytic activity was the same, viz. c. $60 \%$. Typical results are 
shown in Table 1, where the figures represent means of several determinations and have been brought to the nearest round numbers.

Table 1. Adsorption by autoclaved Bact. coli cells of bacteriolytic (Lyt.) enzymes and proteolytic enzymes (Cas., casein substrate) from solutions of streptomyces preparation, crude trypsin and crystalline trypsin

\begin{tabular}{lcc} 
& \multicolumn{2}{c}{ Adsorption of enzymic activity (\%) } \\
\cline { 2 - 3 } & Lyt. units & Cas. units \\
Streptomyces preparation & $\mathbf{7 9}$ & $\mathbf{2 3}$ \\
Crude trypsin & $\mathbf{6 6}$ & $\mathbf{4 5}$ \\
Crystalline trypsin & $\mathbf{5 9}$ & $\mathbf{5 8}$
\end{tabular}

Although the bacteriolytic activity of the streptomyces preparation, and of the crude trypsin, could not be ascribed solely to their caseinolytic activities it could not be concluded that enzymes other than proteolytic enzymes were responsible for the bacteriolysis. It was quite possible that there might be proteolytic enzymes which were unable to digest casein but which were nevertheless able to lyse the killed organisms. Therefore the adsorption of enzymes capable of digesting the protein(s) present in autoclaved Bact. coli was studied. The concentrations of Lyt. and Col. units of solutions of the streptomyces preparation, crude trypsin and crystalline trypsin were determined before and after treatment of the enzyme solutions with autoclaved Bact. coli. Typical results of such experiments are shown in Table 2.

Table 2. Adsorption by autoclaved Bact. coli cells of bacteriolytic (Lyt.) enzymes and proteolytic enzymes (Col., Bact. coli protein substrate) from solutions of streptomyces preparation, crude trypsin and crystalline trypsin

Adsorption of enzymic activity (\%)

Streptomyces preparation

Crude trypsin

Crystalline trypsin

$\begin{array}{cc}\text { Lyt. units } & \text { Col. units } \\ 63 & 59 \\ 59 & 57 \\ 36 & 34\end{array}$

These results strongly suggest that the lysis of killed Bact. coli by the streptomyces preparation and by crude and crystalline trypsin can be accounted for by the proteolytic activity of these preparations. Proteolytic enzymes are adsorbed before bacteriolysis, and during bacteriolysis the bacterial proteins are digested. In the case of crystalline trypsin the bacteriolytic activity is apparently due to the caseinolytic activity. Both the streptomyces preparation and the crude trypsin contained at least two proteolytic enzymes, one caseinolytic and the other capable of digesting the protein(s) of Bact. coli. The caseinolytic enzyme in the crude trypsin preparation is probably the same enzyme as that in the crystalline trypsin preparation, which is bacteriolytic. Whether the caseinolytic enzyme present in the streptomyces preparation is bacteriolytic remains to be seen. 
These experiments show that if the streptomyces preparations contained no other enzymes besides those capable of digesting the protein in autoclaved Bact. coli they would be capable of bacteriolysis. They do not necessarily prove that other, non-proteolytic enzymes are not involved in bacteriolysis. The streptomyces preparation apparently did not contain any enzymes capable of breaking down the polysaccharides in Bact. coli. A suspension (0.04\% dry wt./v) of autoclaved Bact. coli was digested at $37^{\circ}$ with the streptomyces preparation and the amount of total $\left(\mathrm{NH}_{4}\right)_{2} \mathrm{SO}_{4}$-precipitable polysaccharide determined at intervals by the method of Pirie (1939). After $2 \mathrm{hr}$. the organisms were practically completely lysed, but there was no significant diminution in the amount of $\left(\mathrm{NH}_{4}\right)_{2} \mathrm{SO}_{4}$-precipitable polysaccharide. Results of a typical experiment are shown in Table 3.

Table 3. Lysis and proteolysis of autoclaved Bact. coli by the streptomyces preparation, showing apparent absence of polysaccharases

$\begin{array}{cccc}\text { Time } & \text { Lysis } & \begin{array}{c}\text { Increase in } \\ \mathrm{D}_{280} \text { of TCA* } \\ \text { filtrates }\end{array} & \begin{array}{c}\left(\mathrm{NH}_{4}\right)_{2} \mathrm{SO}_{4}- \\ \text { precipitable } \\ \text { polysaccharide } \\ (\mu \mathrm{g} . / \mathrm{ml} .)\end{array} \\ 0 & -\%) & - & 17 \cdot 4 \\ 10 & - & 0 \cdot 025 & 16 \cdot 7 \\ 20 & \mathbf{3 0 \cdot 7} & 0 \cdot 062 & 17 \cdot 5 \\ 40 & 64 \cdot 3 & 0 \cdot 072 & 17 \cdot 2 \\ 60 & 71 \cdot 7 & 0 \cdot 080 & 16 \cdot 8 \\ 120 & 84 \cdot 5 & 0 \cdot 100 & 16 \cdot 0 \\ & * \text { TCA } & & \end{array}$

\section{Death of the organism as a prerequisite of bacteriolysis}

The resistance of living tissues to the action of proteolytic enzymes is a problem that has fascinated biologists for a long time (see Northrop, Kunitz \& Herriott, 1948). Some living micro-organisms are lysed by non-proteolytic enzymes like lysozyme, but living Bact. coli are apparently not lysed by the streptomyces preparation. We have studied the lysability of Bact. coli killed in a number of ways, but we have not been able to throw any light on the problem.

Lysis of heat-killed organisms. Bact. coli suspensions were subjected to various temperatures for various times, and the following observations were made: (a) the viable count of the organisms; (b) the degree of lysis by the streptomyces preparation and by crude trypsin; $(c)$ the degree of adsorption of the bacteriolytic activity of these preparations. Fig. 6 is typical of the results obtained. Similar curves were obtained when the organisms were heated at the temperatures shown for 40, 70 and 120 min., and when crude trypsin was used instead of the streptomyces preparation.

At $c .55^{\circ}$ all the organisms were killed, but there was no appreciable lysis in $15 \mathrm{~min}$., and c. $25 \%$ of the maximum adsorbable bacteriolytic activity was adsorbed. Only at $70^{\circ}$ did the organisms become markedly lysable.

Although organisms killed by heating at $55^{\circ}$ do not appear to be lysed in 
$15 \mathrm{~min}$. they are nevertheless lysed when exposed to the lytic agent for $\mathbf{3} \mathrm{hr}$. Table 4 shows the lysis of organisms killed at $55^{\circ}$ by the streptomyces preparation and by crude trypsin. The control experiment, in which the organisms were suspended in phosphate buffer alone, shows that appreciable autolysis takes place during the experimental period. Presumably the marked lysis of organisms which had been heated above $70^{\circ}$ was due to the denaturation of bacterial protein.

Table 4. Autolysis, and lysis by the streptomyces preparation and crude trypsin, of Bact. coli cells killed by heating at $55^{\circ}$ for $1 \mathrm{hr}$.

Lysis at $37^{\circ}(\%)$

after periods of time shown

$\quad$ Lytic agent
Phosphate buffer
Streptomyces preparation
Crude trypsin

$\begin{array}{ccc} & & \\ 15 \text { min. } & 1 \mathrm{hr} . & 3 \mathrm{hr} . \\ 4.2 & 10.5 & 16.8 \\ 8.7 & 20.1 & 43.8 \\ 7.6 & 16.6 & 35.4\end{array}$

Lysis of organisms killed by other means. A study was made of the lysis of suspensions of Bact. coli killed by the following means : (a) standing for 12 days in distilled water; $(b)$ treatment with a $1 \mathrm{mg} . / \mathrm{ml}$. concentration of polymyxin $\mathbf{E}$ (Burroughs Wellcome Ltd. 'Aerosporin'); (c) treatment with a $3 \mathrm{mg} . / \mathrm{ml}$. concentration of polymyxin. When Bact. coli was suspended in distilled water for 12 days $90.1 \%$ of the organisms died. Practically all the organisms were killed after exposure to $1 \mathrm{mg}$. polymyxin/ml. for $3 \mathrm{hr}$.

The results for the lysis of the organisms killed by these means are given in Table 5.

Table 5. Lysis by autolytic enzymes, by the streptomyces preparation, and by crude trypsin of 'living' Bact. coli, and of organisms killed by various means

\begin{tabular}{|c|c|c|c|c|}
\hline \multirow[b]{2}{*}{ Lytic agent } & \multirow{2}{*}{$\begin{array}{c}\text { Treatment of } \\
\text { Bact. coli }\end{array}$} & \multicolumn{3}{|c|}{ Lysis at $37^{\circ}(\%)$ after } \\
\hline & & $15 \mathrm{~min}$. & $1 \mathrm{hr}$. & $3 \mathrm{hr}$. \\
\hline $\begin{array}{l}\text { Phosphate buffer } \\
\text { Streptomyces preparation } \\
\text { Crude trypsin }\end{array}$ & 'Living' organisms & $\begin{array}{l}4 \cdot 9 \\
6 \cdot 7 \\
8 \cdot 1\end{array}$ & $\begin{array}{l}11 \cdot 0 \\
13 \cdot 9 \\
15 \cdot 5\end{array}$ & $\begin{array}{l}23 \cdot 4 \\
26 \cdot 7 \\
25 \cdot 3\end{array}$ \\
\hline $\begin{array}{l}\text { Phosphate buffer } \\
\text { Streptomyces preparation } \\
\text { Crude trypsin }\end{array}$ & $\begin{array}{l}\text { Organisms dead after } \\
\text { standing in distilled } \\
\text { water for } 12 \text { days }\end{array}$ & $\begin{array}{l}11 \cdot 4 \\
18 \cdot 5 \\
18 \cdot 8\end{array}$ & $\begin{array}{l}22 \cdot 0 \\
33 \cdot 5 \\
30 \cdot 5\end{array}$ & $\begin{array}{l}37 \cdot 5 \\
45 \cdot 5 \\
42 \cdot 6\end{array}$ \\
\hline $\begin{array}{l}\text { Phosphate buffer } \\
\text { Streptomyces preparation } \\
\text { Crude trypsin }\end{array}$ & $\begin{array}{l}\text { Organisms killed with } \\
\text { polymyxin } 1 \mathrm{mg} . / \mathrm{ml} \text {. } \\
\text { for } 3 \mathrm{hr} \text {. }\end{array}$ & $\begin{array}{l}12 \cdot 0 \\
26 \cdot 3 \\
21 \cdot 7\end{array}$ & $\begin{array}{l}17 \cdot 8 \\
35 \cdot 9 \\
31 \cdot 2\end{array}$ & $\begin{array}{l}25 \cdot 4 \\
44 \cdot 3 \\
39 \cdot 6\end{array}$ \\
\hline $\begin{array}{l}\text { Phosphate buffer } \\
\text { Streptomyces preparation } \\
\text { Crude trypsin }\end{array}$ & $\begin{array}{l}\text { Organisms killed with } \\
\text { polymyxin } 3 \mathrm{mg} . / \mathrm{ml} \text {. } \\
\text { for } 3 \mathrm{hr} \text {. }\end{array}$ & $\begin{array}{l}11 \cdot 6 \\
22 \cdot 2 \\
17 \cdot 8\end{array}$ & $\begin{array}{l}13 \cdot 6 \\
38 \cdot 4 \\
33 \cdot 0\end{array}$ & $\begin{array}{l}17 \cdot 8 \\
48 \cdot 3 \\
43 \cdot 8\end{array}$ \\
\hline $\begin{array}{l}\text { Phosphate buffer } \\
\text { Streptomyces preparation }\end{array}$ & $\begin{array}{l}\text { Organisms autoclaved } \\
\text { at } 120^{\circ} \text { for } 20 \mathrm{~min} .\end{array}$ & $\begin{array}{c}0 \\
\mathbf{3 4} \cdot 4\end{array}$ & $\begin{array}{r}3 \cdot 0 \\
64 \cdot 0\end{array}$ & $\begin{array}{l}7 \cdot 1 \\
\text { Out of } \\
\text { range }\end{array}$ \\
\hline Crude trypsin & & $41 \cdot 5$ & $71 \cdot 1$ & $\begin{array}{l}\text { Out of } \\
\text { range }\end{array}$ \\
\hline
\end{tabular}


All the lysis of living organisms (bearing in mind that a suspension of living organisms must contain many dead organisms) is due to autolysis; but organisms which have been killed by comparatively gentle means are to some extent lysable by the streptomyces preparation and by crude trypsin. The change that takes place when an organism dies, rendering it susceptible to lysis, is not known. All we do know is that dead organisms adsorb more of the lytic agent than living organisms. This is shown in Table 6.

Table 6. Adsorption of bacteriolytic activity from the streptomyces preparation by 'living' Bact. coli, and by organisms killed by various means

Treatment of Bact. coli

Living

Dead after standing in distilled water for 12 days

Killed by heating at $55^{\circ}$ for $1 \mathrm{hr}$.

Killed by treatment with $1 \mathrm{mg}$. polymyxin $/ \mathrm{ml}$. for $3 \mathrm{hr}$.

Autoclaved at $120^{\circ}$ for $20 \mathrm{~min}$.
Adsorption of bacteriolytic activity from streptomyces preparation (\%)

10.4

$16 \cdot 7$

26.5

34.5

$69 \cdot 8$

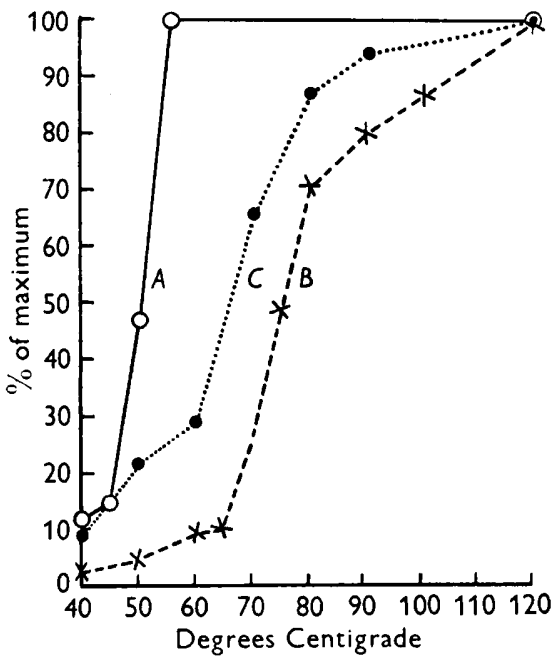

Fig. 6

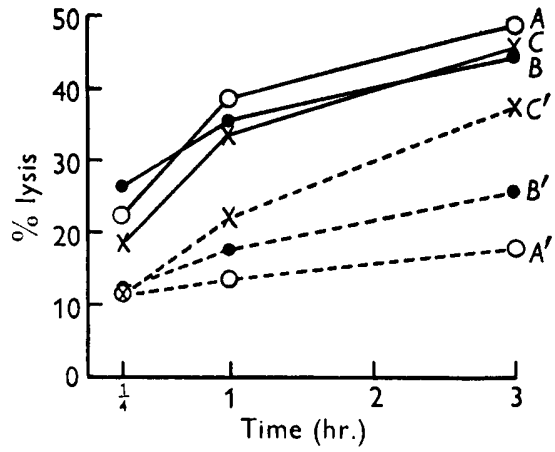

Fig. 7

Fig. 6. Effect of heating for $10 \mathrm{~min}$. on: $(A)$ mortality of Bact. coli; $(B)$ degree of lysis of Bact. coli; $(C)$ the degree of adsorption of bacteriolytic activity. Bacteriolytic agent, the streptomyces preparation. Values of ordinate are given as percentage of maximum attainable at $120^{\circ}$.

Fig. 7. Autolysis and lysis by the streptomyces preparation of Bact. coli killed by: (A) polymyxin, $3 \mathrm{mg} . / \mathrm{ml}$; $(B)$ polymyxin $1 \mathrm{mg} . / \mathrm{ml}$.; $(C)$ standing in distilled water for 12 days. $A, B, C$, lysis; $A^{\prime}, B^{\prime}, C^{\prime}$, autolysis.

\section{Autolysis}

A re-examination of the data in Table 5 might throw some light on the autolysis of Bact. coli. 'Living' organisms autolyse to some extent; autoclaved organisms hardly autolyse at all, presumably because the autolytic enzymes 
have been destroyed. Organisms killed by more gentle means autolyse more than 'living' organisms. Pulvertaft \& Lumb (1948) observed that organisms killed with minimal concentrations of antiseptics undergo extensive autolysis. Organisms that have been killed with $3 \mathrm{mg}$. polymyxin/ml. autolyse less than organisms that have been killed with $1 \mathrm{mg}$. polymyxin/ml., although the degree of lysis by the streptomyces preparation is about the same in both cases. This suggests that the higher concentration of polymyxin has inhibited the autolytic enzymes. The degree of lysis by the streptomyces preparation of organisms killed by standing in distilled water for 12 days, or by treatment with 3 or $1 \mathrm{mg}$. polymyxin $/ \mathrm{ml}$. is much the same irrespective of the autolysis of these organisms (see Fig. 7). This suggests that the effects of the streptomyces enzymes and the autolytic enzymes are not additive, and therefore that the streptomyces enzymes and the autolytic enzymes act upon different substrates. Possibly proteolytic enzymes play only a small part in autolysis.

We are grateful to Prof. Sir Howard Florey, F.R.S., for his encouragement and interest in this work, to Dr G. V. R. Born for collaboration in certain experiments, to Dr Kathleen Crawford for identifying the organism, and to Miss Megan Lancaster for technical assistance. One of us (T.Y.T.) held a scholarship from the Chinese Government and grants from the University of Oxford and the British Council which are gratefully acknowledged.

\section{REFERENCES}

van Heyningen, W. E. (1949). A rapid concentrating still. Brit. J. exp. Path. 30, 202.

Jones, A. S., Swallow, A. J. \& WebB, M. (1948). The exocellular bacteriolytic system of soil actinomyces. 1. The nature and properties of the lytic system. Biochem. Biophys. Acta, 2, 167.

Kunitz, M. (1947). Crystalline soybean trypsin inhibitor. II. General properties. J. gen. Physiol. 30, 291.

Northrop, J. H., Kunitz, M. \& Herriott, R. M. (1948). Crystalline Enzymes, 2nd ed. New York: Columbia University Press.

Prrie, Antoinette (1939). A chemical change occurring during the lysis of Bact. coli by bacteriophage. Brit. J. exp. Path. $20,99$.

Pulvertaft, R. J. V. \& Lumb, G. D. (1948). Bacteriolysis and antiseptics. J. Hyg., Camb., 46, 62.

TaI, T. Y. \& van Heyningen, W. E. (1950). An easy method for counting bacterial colonies in roll tubes. Brit. J. exp. Path. 31, 155.

Thompson, L. C. (1946). An inorganic grey solution. Trans. Faraday Soc. 42, 663.

Waksman, S. A. (1947). Microbial Antagonisms and Antibiotic Substances, 2nd ed. New York: The Commonwealth Fund.

Welsch, M. (1947). Phénomènes d'antibiose chez les Actinomycètes. Gembloux: Imprimerie J. Duculot.

(Received 3 April 1950) 